\title{
Kven kan vita?
}

\section{Gjennom livet har eg fått erfara kor uvisst livet kan te seg - om det ser aldri så sikkert ut.}

«Du har høgst tre månader igjen å leva!» sa den unge legen til min nære slektning då ho vakna etter kreftoperasjonen. Eg sat hos henne like etter den sjokkerande beskjeden som fekk kvinna til å lukka augo for omverda og seia at døden skal sleppa å venta på meg! Alt hadde gått så fort! Optimismen ho hadde fått med seg då ho reiste frå lokalsjukehuset, hadde med eitt blitt knust av tunge tankar og dødsangst.

Du har kreft, men det er håp! Hadde dei sagt der - idet ho fór av stad til Haugesund sjukehus. Eg kunne berre roa meg, for dette skulle ho greia. Sa ho.

Eg kom til Haugesund like etter operasjonen, men då var domen felt. Døden hadde alt fătt overtaket.

Då eg fortalde ein sjukepleiar kva eg meinte om det som var blitt sagt, fekk eg berre høyra: Ja, men det er jo sannheten!

Men er det alltid sanninga? Ein annan lege på same sjukehuset hadde sagt til borna at mora kunne ha månader igjen men også år. For ein kan aldri vita!

Gjennom livet har eg fått erfara kor uvisst livet kan te seg - om det ser aldri så sikkert ut.

Mor hadde hatt fleire små hjarteinfarkt. Då ho, 92 år gamal, igjen kom på sjukehuset, strevde ho så tungt med pusten at legen bad meg om å overnatta. «For mor di lever nok ikkje over natta», sa han.
Timane gjekk. Ein ny lege overtok vakta og kalla meg inn til seg med same beskjeden. Det vart ei uroleg natt. Men mor overlevde.

14 dagar seinare var ho frisk nok til å dra frå sjukehuset til rehabilitering. Endå ein gong vart eg innkalla til legekontoret for å få vita at mor hadde ein «meget sterk hjertesvikt» og kort tid igjen å leva. Dette var ved påsketider, så eg uttrykte von om at ho fekk oppleva sommaren i lag med far i hagen med alle blomane og fuglane. À nei - det kunne eg ikkje rekna med, var svaret.

Først den tredje sommaren sovna mor stille inn - i heimen sin, utan pusteproblem - 95 år gamal.

Tidlegare kunne eg reagera på korleis pårørande, med unntak av den sjuke, fekk vita kor dårleg det stod til. Nå reagerer eg på at sanninga kan bli pressa på oss samstundes som me får høyra kor viktig det er å leva med håpet.

Ei småbarnsmor vart operert for ein hjernesvulst som var så smertefull at ho gløymde alle rundt seg. Då ho vakna etter operasjonen, heilt smertefri, kom livsgneisten tilbake. Endeleg fekk ho vera mor og ektemake igjen. Men det skulle ikkje vara lenge. Ein dag ho var til kontroll, kom ein pleiar til å fortelja at «her ser det ikkje bra ut, men du har jo kreft»!

Kreft? Det hadde ikkje veninna mi fått vita. Ho gjekk rett inn i depresjonen igjen. Alt vart teke frå henne som ville gjort henne sterkare til å møta det som kunne koma.

Også dei eldste av oss kan kjempe for livet sitt. Jørgen var 104 år då han fekk dobbeltsidig lungebetennelse med hjartesvikt. På sjukehuset hadde visst alle tenkt at dette var siste turen hans. Han måtte tigga etter mat. Men Jørgen kom seg heim igjen. Der sa han til barnebarnet sitt: «Du hadde vel ynskt at eg skulle døy nå, så du fekk arven din!»

«Å nei, bestefar - nå må du leva til du blir 110 år», svara barnebarnet.

«Det svaret likte eg», sa 104-åringen, som fekk eit aktivt liv til han vart 110 , heilt klår til siste stund. Dette skreiv dottera i brevet til meg.

Var det det uventa svaret til barnebarnet som gav den gamle ekstra styrke og motivasjon? Ein kan berre undra - for korleis ville han kjent det om barnebarnet hans hadde venta med å svara?

Sjølv har eg enno ikkje kome i ein slik situasjon, men har erfart kor mykje styrke det ligg i å ikkje vita. For kven veit? Og kven kan det gagna? Me lever jo heile livet vårt i det uvisse. Den fridomen må me få leva i så lenge det er liv i oss og me ikkje sjølv spør etter svaret!

Ingen har lova oss morgondagen.

Og korleis hadde det gått med mor, som fekk oppleva to somrar, tre vintrar og vårar, om det var ho - og ikkje eg - som ved påsketider tre år tidlegare fekk vita at ho ville døy før sommaren kom?

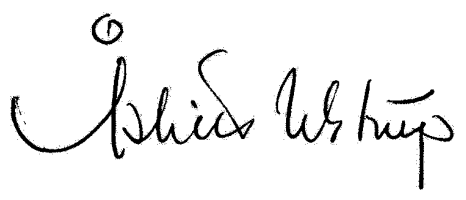

